\title{
ПРОФЕСІЙНА ГОТОВНІСТЬ ВИКЛАДАЧІВ ДО ЗДІЙСНЕННЯ ІННОВАЦІЙНОЇ ПЕДАГОГІЧНОЇ ДІЯЛЬНОСТІ
}

\author{
Резунова О. С., Передерій О. Л.
}

\section{ВСТУП}

Готовність викладача до здійснення професійної діяльності $€$ невід'ємною частиною професійної компетентності педагога. Умови сьогодення, а саме стрімка глобалізація, інформатизація, значний ріст технологій, необхідність працювати за умов пандемії висувають нові вимоги до викладача та його особистісно-професійних якостей. Основна задача національної освіти - створити умови для розвитку і саморозвитку кожної особистості, сформувати покоління, яке буде спроможне навчатися упродовж усього життя, створювати і розвивати цінності громадянського суспільства. Саме тому зараз потрібні викладачі, здатні працювати 3 використанням нових технологій, підходів, форм і методів педагогічної діяльності.

Найсуттєвішою ознакою реформування сучасних освітніх систем є їхня «інноваційність», що проявляється в апробації викладачами вітчизняних i зарубіжних освітніх технологій, альтернативних традиційним. Крім того, інноваційна педагогічна діяльність впроваджується через створення авторських навчальних програм, технологій тощо. Тому важливим складником професіоналізму викладачів стає їхня готовність до оцінки нових педагогічних технологій, визначення їх відповідності потребам i можливостям конкретного закладу освіти, готовність до впровадження в освітній процес інноваційних форм і методів роботи, тобто готовність до інноваційної педагогічної діяльності.

\section{1. Трактування основних понять дослідження: «моніторинг», «професійна готовність», «інноваційна діяльність»}

Пріоритетом розвитку освіти у XXI ст. світове співтовариство визнало ii якість, а нові стандарти вищої освіти чітко визначають коло професійних і загальних компетенцій, якими повинен володіти спеціаліст відповідно до освітнього ступеня отриманої фахової освіти ${ }^{1}$. Згідно 3

${ }^{1}$ Семак Л.А. Педагогічні передумови формування мовленнєвої компетентності здобувачів вищої освіти. Гуманітарний вісник. 2020. Вип. 32. С. 51-53. URL: http://enpuir.npu.edu.ua/bitstream/123456789/29510/1/Hum-Korpus32.pdf\#page=51 (дата звернення: 09.12.2020). 
Національною стратегією розвитку освіти в Україні на 2012-2021 pp. одним із пріоритетних стратегічних напрямів розвитку освіти є створення національної системи моніторингу іiі якості. Оцінювання якості освіти стає елементом iї ефективного управління, тому моніторинг $\epsilon$ невід'ємною складовою частиною ії організації, адже дозволяє оцінити відповідність освіти певним стандартам, спрогнозувати перспективи розвитку та розробити управлінські впливи.

Запровадження моніторингових досліджень у різних сферах діяльності здійснюється у студіях таких вчених, як I. Аннєнкова, Н. Байдацька, Л. Васильченко, Т. Волошина, А. Дахін, Г. Сльникова, В. Заїка, Н. Круглова, I. Лапшина, О. Локшина, Т. Лукіна, К. Лупінович, С. Лупінович, А. Майоров, I. Макаренко, М. Мартиненко, В. Мозальов, С. Нестеренко, Т. Олендр, О. Островерх, Н. Пастухова, В. Рєпкін, Г. Рєпкіна, 3. Рябова, Л. Тарасюк, Д. Вілмс, А. Харківська, Є. Хриков, О. Чорна, Л. Щоголєва та ін.

Термінологічні джерела тлумачать поняття «моніторинг» дещо порізному. Так, укладачі словника іншомовних слів зазначають походження слова від англ. «monitor» - спостерігати, а сам термін трактується як постійний контроль за будь-яким процесом із метою вивчення відповідності цього процесу бажаному результату ${ }^{2}$. У Великому тлумачному словнику сучасної української мови «моніторинг» - безперервне стеження за будь-яким процесом із метою виявлення його відповідності бажаному результату ${ }^{3}$.

У педагогічних науках моніторинг розглядається: як засіб, який дозволяє безупинно та тривало спостерігати за освітнім процесом із метою виявлення ефективності, раціональності того чи іншого педагогічного методу ${ }^{4}$; як супроводжуюче відстеження та поточна регуляція будь-якого процесу в освіті, що базується на певних показниках, об'єднаних у стандарт, і відповідно до цих показників відбувається спостереження за станом і динамікою керованого об'єкта 3 метою його оперативної діагностики, вироблення та корегування управлінських рішень ${ }^{5}$; як система збору, опрацювання й поширення інформації про діяльність освітньої системи, що забезпечує безперервне спостереження за іiі станом і забезпечує прогноз іiі

2 Словник іншомовних слів / Л.О. Пустовіт, О.І. Скопненко, Г.М. Сюта, Т.В. Цимбалюк. Київ : Вид-во «Довіра» УНВЦ «Рідна мова», 2000. С. 287.

${ }^{3}$ Новий тлумачний словник української мови : у 3 т. / уклад. В. Яременко, О. Сліпушко. Київ : Аконіт, 2001. Т. 3. С. 538.

4 Дахин А.Н. Педагогический мониторинг: концепция и применение. URL: http://www.iuro.websib.ru/dak.htm (дата звернення: 20.09.2020). C. 36-37.

5 Єльникова Г.В., Рябова 3.В. Моніторинг як ефективний засіб оцінювання якості загальної середньої освіти в навчальному закладі. Культура народов Причерноморья. 2007. № 115. Т. 1. С. 35-43. 
розвитку ${ }^{6}$; як дієвий засіб менеджменту освіти, який дозволяє управляти її якістю через отримання кількісних і якісних показників ${ }^{7}$.

Цілком погоджуємося 3 думкою А. Харківської ${ }^{8}$, котра розглядає педагогічний моніторинг як дієвий спосіб управління якістю освіти, що дозволяє забезпечити якість усіх головних складників освітнього процесу, а саме цілей, змісту освіти, матеріально-технічної бази, організації освітнього процесу.

Отже, головним результатом попереднього тематичного аналізу наукової теорії ми вважаємо усвідомлення того, що абсолютну більшість авторів об'єднує розуміння суті моніторингу як концептуально повноцінної функціональної системи, покликаної забезпечити належну якість освіти.

Чітко сформульовані принципи освітнього моніторингу подано в роботах О. Локшиної ${ }^{9}$, Є. Хрикова, ${ }^{10}$ Л. Щоголєвої ${ }^{11}$. Серед них основними є принципи узгодженості нормативно-правового, організачійного та наукового забезпечення його складових частин; валідності - відповідності пропонованих контрольних завдань змістові досліджуваного матеріалу, чіткості критеріїв виміру й оцінки; систематичності - проведення моніторингу у певній послідовності (етапами); об'єктивності, тобто врахування усіх результатів (позитивних i негативних) i комплексності дослідження; безперервності та тривалості спостережень; своєчасності отримання, обробки та використання об'єктивної інформацї; рефлективності, яка виявляється у відображенні якості результатів, здійсненні самооцінки та самоконтролю; урахування психологопедагогічних особливостей; гуманістичної спрямованості моніторингу.

Щоб забезпечити адекватне застосування понятійного апарату у нашому науковому досліджені при розробці системи моніторингу,

6 Тарасюк Л.В Моніторинг рівня професійної майстерності вчителя сучасної школи. Теорія та методика управління освітою. Т. 1 (22). 2019. URL: http://umo.edu.ua/images/content/nashi_vydanya/metod_upr_osvit/v_22/\%D0\%A2\%D0\%B 0\%D1\%80\%D0\%B0\%D1\%81\%D1\%8E\%D0\%BA.pdf (дата звернення: 07.12.2020). C. 8.

7 Майоров А.Н. Мониторинг в образовании. Кн. 1. Санкт-Петербург : Образование-Культура, 1998. 344 с.

${ }_{8}^{8}$ Харківська А. Сутність педагогічного моніторингу якості виховного процесу у вищих педагогічних навчальних закладах. Обрії. 2013. № 2. С. 92-95.

9 Моніторинг якості освіти: світові досягнення та українські перспективи : посібник / за заг. ред. Локшиної О.І. Міністерство освіти і науки України. Київ : K.I.C., 2004. 128 c.

${ }_{10}$ Хриков Є.M. Теоретико-методологічні засади моніторингу професійної підготовки. URL: http://www.prof.osvita.org.ua/uk/ career/articles/2.html (дата звернення: 09.12.2020).

11 Щоголєва Л.О. Моніторинг якості освіти: теоретико-методологічний аспект. Педагогічний пошук. 2014. № 2 (82). С. 36-40. 
уточнимо також сутність понять «професійна готовність» та «інноваційна діяльність».

Н. Мазур ${ }^{12}$ у своїх дослідженнях виділяє два підходи до визначення поняття «готовність»: згідно 3 першим готовність трактується як певний психічний стан, із другим - як певна властивість або система властивостей i якостей особистості. Дослідниця виділяє головну схожість цього феномену у поглядах вчених: більшість включає в поняття готовності наявність знань, вмінь, досвіду діяльності та сформованого ставлення особистості до майбутньої професії, яке полягає у прагненні самореалізуватися в ній.

Роздуми щодо готовності знаходимо i в роботах К. ДурайНоваковської $^{13}$, яка розуміє іiі як систему інтегративних якостей, властивостей, знань і навиків особистості.

Феномен «професійна готовність» привернув до себе увагу вчених i став об'єктом спеціальних наукових досліджень ще у XIX ст. Поняття професійної готовності педагогів розглядається 3 різних позицій, але найчастіше науковці вживають його у значенні функцій викладача у практичному значенні його вмінь.

У різні часи проблему формування професійної готовності та iї структуру вивчали М. Кулакова, Л. Мірошниченко, Л. Бєкірова, I. Гавриш, Л. Дзюба-Шпурик, О. Дуплійчук, К. Дурай-Новакова, В. Ковалев, Л. Коваль, Д. Пащенко, А. Поляков, В. Сластьонін, О. Шапран та ін.

Найбільш значущу для нашого дослідження трактовку поняття «готовність до професійної діяльності» та ії компонентів знаходимо у працях В. Сластьоніна ${ }^{14}$. Разом із ученим ми переконані, що готовність до професійної діяльності $\epsilon$ невід'ємною складовою частиною професійної компетентності спеціаліста, а виявлятися цей феномен має y здатності ідентифікувати себе з іншими, у відповідному психологічному стані, який відображає динамізм особистості, багатство iї внутрішньої енергії, ініціативність, волю, винахідливість та емоційну стійкість; y наявності професійного мислення, що дозволяє виявляти причинно-наслідкові зв'язки, аналізувати свою діяльність, відшукувати науково обгрунтовані пояснення успіхів і невдач, а також передбачати результати роботи.

12 Мазур Н. Поняття «готовності» та визначення структурних компонентів готовності майбутніх вчителів інформатики. Наукові записки Кіровоградського державного педагогічного університету імені Володимира Винниченка. Серія : Педагогічні науки. 2013. № 121 (2). С. 283-287.

13 Дурай-Новаковская М. Основы и закономерности процесса формирования профессиональной готовности к педагогической деятельности : автореф. дисс. ... докт. пед. наук. Москва, 1983. 41 с.

14 Сластенин В.А. Профессиональная готовность учителя к воспитательной работе. Советская педагогика. 1981. № 4. С. 76-84. 
Аналіз наукових джерел виявив певні розходження стосовно кількості компонентів готовності до професійної діяльності педагогів. Так, вчені М. Дьяченко та Л. Кандибович виділяють п'ять компонентів: мотиваиійний, орієнтаиійний, операціональний, вольовий та оиіночний 15 . Оціночний, на думку вчених, виявляється за наявності у спеціаліста потреби успішно виконувати поставлену задачу, зацікавленості в об'єкті діяльності, у прагненні до успіху; орієнтаційний компонент має включати знання й уявлення про особливості й умови діяльності; наявність операціонального компоненту передбачає володіння способами та прийомами діяльності, вміннями та навиками; вольовий компонент характеризується внутрішньою потребою індивіда в управлінні своїми діями; вміння особистості надати самооцінку своїй підготовленості та відповідності процесу розв'язання професійних задач становить оціночний компонент.

$€$. Зеєр, О. Конюхова ${ }^{16}$ включають до структури професійної готовності чотири компоненти, а саме: мотиваційний, пізнавальний, емоційний і вольовий. Мотиваційний компонент виявляється у потребі праці, зацікавленості професією, а також в уявленні про соціальний статус, престижність професії, матеріальній зацікавленості; пізнавальний компонент включає розуміння соціальної значущості обраної професії, знання шляхів досягнення мети; гордість за професію, естетичне ставлення до професійної майстерності становлять емоційний компонент; вольовий компонент передбачає уміння мобілізувати свої сили, долати труднощі на шляху до мети.

H. Іпполітова ${ }^{17}$ виокремлює три взаємопов'язані компоненти готовності педагога до професійної діяльності: особистісний, когнітивний і праксикологічний компоненти. Особистісний компонент включає ступінь морально-педагогічної готовності вчителя до професійної діяльності, а також відображає рівень сформованості ціннісних орієнтацій, інтерес до професії, рівень розвитку мотивації; когнітивний компонент відображає рівень інформованості педагога про сутність i зміст педагогічної діяльності, наявність загальнопедагогічних, методичних, спеціально-предметних знань, необхідних для ефективної професійно-педагогічної діяльності; наявність професійних вмінь і навичок, необхідних для реалізації педагогічної діяльності та забезпечення іiї ефективності, визначає праксикологічний компонент.

15 Дьяченко М.И., Кандыбович Л.А. Психологические проблемы готовности к деятельности. Минск : Изд-во Бел. ун-та, 1976. 175 с.

16 Зеер Э.Ф., Конюхова Е.Т. Психологические факторы влияния установки педагогов на инновационную деятельность. Образование и наука. 2010. № 4 (72). С. 41-49.

17 Ипполитова Н.В., Колесников М.А., Соколова Е.А. Система профессиональной подготовки студентов педагогического вуза: личностный аспект : монография. Шадринск : Исеть, 2006. 236 с. 
Погоджуючись із думкою В. Масленнікової ${ }^{18}$, вважаємо, що одним iз найголовніших компонентів готовності викладача до педагогічної діяльності $\epsilon$ моральний компонент, який включає певний комплекс якостей особистості. Професія педагога належить до соціально значущих професій, що вимагають працювати 3 повною віддачею в інтересах суспільства, виявляючи почуття відповідальності, самостійності, наполегливості у досягненні поставленої мети, творче виконання професійних функцій.

Перейдемо до тлумачення важливого для нашого дослідження терміна «інноваційна діяльність». Проблема інноваційної педагогічної діяльності привертає увагу багатьох науковців і досліджується в різних аспектах: методологічному (І. Гавриш, Г. Корнетов, В. Загвязинський, В. Ляудіс, В. Паламарчук, І. Підласий, О. Савченко, В. Сластьонін), аксіологічному (М. Бургин, М. Кларин, О. Попова, М. Поташник), праксіологічному (С. Сєдова, Л. Струценко, А. Пригожин), методичному (В. Беспалько, О. Піддубцева, А. Вербицький, Н. Осухова, Е. Плеханов), управлінському (Л. Даниленко, В. Кваша, О. Хомерики).

Інновації (від італ. «іnnovatione» - новизна, нововведення) - нові форми організації діяльності й управління, нові види технологій, які охоплюють різні сфери життєдіяльності людства ${ }^{19}$. Крім того, погоджуємося 3 думкою О. Піддубцевої ${ }^{20}$ про те, що на сучасному етапі розвитку педагогічної науки існує багато інноваційних методів викладання.

У педагогічних науках термін «інновація» теж має значну кількість тлумачень. Звернемося до найбільш відповідних для нашого дослідження. Так, О. Савченко ${ }^{21}$ переконана, що під інновацією слід розуміти процес створення, поширення й використання засобів (нововведень) для розв'язання тих педагогічних проблем, які досі розв'язувалися по-іншому. Інновація, на думку І. Дичківської ${ }^{22}$, у контексті педагогічного процесу означає введення нового в цілі, зміст, методи та форми навчання і виховання, організацію спільної

${ }^{18}$ Масленникова В.Ш. Формирование профессиональной готовности студентов среднего профессионального учебного заведения к деятельности социального педагога : автореф. дис. ... докт. пед. наук. Казань, 1996. 38 с.

19 Буга Н.Ю. Становлення наукової та інноваційної діяльності у вищих навчальних закладах. Економіст. 2006. № 9. С. 60-64.

20 Піддубцева О.І. Інноваційні методи формування професійної мобільності майбутніх фахівців-аграріїв. Науковий вісник Національного університету біоресурсів $і$ природокористування Украӥни. Серія : Педагогіка, психологія, філософія. 2017. Вип. 277. С. 199-204. URL: http://nbuv.gov.ua/UJRN/ nvnau_ped_2017_277_37 (дата звернення: 09.12.2020).

${ }_{21}$ Савченко О.Я. Дидактика початкової школи. Київ : Освіта, 1997. 400 с.

22 Дичківська I.M. Інноваційні педагогічні технології : підручник. Київ : Академвидав, 2012. 352 с. 
діяльності вчителя й учня. На думку О. Попової ${ }^{23}$, досліджуваний феномен слід розглядати як цілеспрямований i керований процес внесення змін в освітню практику шляхом створення, розповсюдження й освоєння нововведень. Цікавою є думка М. Кларіна ${ }^{24}$ про те, що інновації належні не тільки до створення і поширення новацій, а й до змін у способах діяльності, стилі мислення, які з цим пов'язані.

Готовність до інноваційної педагогічної діяльності слід розглядати як особливий особистісний стан, який передбачає наявність у педагога мотиваційно-ціннісного ставлення до професійної діяльності, володіння ефективними способами та засобами досягнення педагогічних цілей, здатності до творчості та рефлексії ${ }^{25}$.

Науковці виокремлюють певні компоненти готовності до інноваційної діяльності. Так, О. Гончарова ${ }^{26}$ переконана, що основними компонентами готовності майбутнього вчителя іноземної мови до інноваційної діяльності є мотиваџійний, когнітивний, операційнодіяльнісний і рефлексивний. І. Дичківська до компонентів готовності до інноваційної діяльності відносить: мотиваційний, когнітивний, креативний, рефлексивний. Основними компонентами готовності майбутніх вчителів до інноваційної діяльності, на думку Н. Плахотнюк ${ }^{27}$, є мотиваційний, когнітивно-операційний, креативний, рефлексивний. В. Сластьонін і Л. Подимова ${ }^{28}$ виокремлюють мотивачійний, креативний, технологічний, рефлексивний компоненти готовності педагога до інноваційної професійної діяльності.

Проведений нами аналіз наукових джерел дозволив розробити власну систему моніторингу професійної готовності вчителів до інноваційної діяльності, спираюсь на зазначені нами раніше науково обгрунтовані педагогічні вимоги, принципи, методи, етапи його проведення.

${ }^{23}$ Попова О.В. Становлення і розвиток інноваційних педагогічних ідей в Україні в ХХ столітті. Харків : ОВС, 2001. 256 с.

24 Кларин М.В. Педагогическая технология в учебном процессе. Москва, 1989. $225 \mathrm{c}$.

${ }^{25}$ Дичківська I.M. Інноваційні педагогічні технології : навчальний посібник. Київ : Академвидав, 2004. 352 с.

${ }^{26}$ Гончарова О.А. Педагогічні умови підготовки майбутнього вчителя іноземної мови до інноваційної діяльності : автореф. дис. ... канд. пед. наук : 13.00.04. Київ, 2008. $20 \mathrm{c}$.

27 Плахотнюк Н.П. Критерії та показники рівня готовності майбутніх учителів до інноваційної діяльності. Збірник наукових праць Слов'янського державного педагогічного університету. Ч. II. (5). С. 181-191.

${ }^{28}$ Сластенин В.А., Подымова Л.С. Педагогика: Инновационная деятельность. Москва : Магистр, 1997. 224 с. 


\section{2. Моніторинг професійної готовності викладачів до інноваційної діяльності}

Нами були визначені такі компоненти професійної готовності викладачів до здійснення інноваційної діяльності: особистіснорефлексивний (реалізується цей компонент через такі рефлексивні процеси, як саморозуміння й розуміння іншого, самооцінювання й оцінювання іншого, самоінтерпретація й інтерпретація іншого), мотиваційний (мотиви здійснення інноваційної діяльності викладача, прагнення до успіху, позитивне ставлення та пізнавальний інтерес до інновацій у професійній діяльності, прагнення до активної участі у створенні, запровадженні та поширенні педагогічних інновацій), креативний (творче осмислення та пошук нестандартних шляхів розв'язання педагогічних проблем). Оцінювання кожного компонента здійснювалося за чотирма рівнями: низьким, середнім, достатнім і високим.

Процес моніторингу був проведений у три етапи. $\mathrm{Ha}$ організаційному етапі нами було визначено мету моніторингу, респондентів, розроблено авторські анкети, підібрано методики.

Мета моніторингу - виявити ступінь професійної готовності викладачів до інноваційної діяльності з метою удосконалення освітньої системи щодо впровадження педагогічних інновацій.

Для моніторингу використано всебічно обгрунтовані, апробовані на практиці методики, що суттєво підвищило достовірність результатів. Це такі методичні засоби: анкета «Виявлення здібностей до саморозвитку та саморефлексії», тест «Оцінка рівня творчого потенціалу особистості», розроблені В. Бліновою та Ю. Бліновою ${ }^{29}$, «Методика діагностики особистості на мотивацію до успіху Т. Елерса» ${ }^{30}$, адже, на думку С. Цимбал ${ }^{31}$, мотивація $є$ досить потужним стимулятором діяльності.

Моніторинг було проведено у п'яти закладах вищої освіти, а саме: Дніпровському державному аграрно-економічному університеті (далі ЗВО № 1), КЗВО «Дніпровська академія неперервної освіти» (далі ЗВО № 2), Придніпровській державній академії будівництва та архітектури (далі - ЗВО № 3), ДЗ «Дніпропетровська медична академія» МО3 України (далі - ЗВО № 4), Університеті митної справи та фінансів (далі - ЗВО № 5). Основними методами збору інформації були тестування, анкетування, співбесіди.

29 Блинова В.Л., Блинова Ю.Л. Психологические основы самопознания и саморазвития : учебно-методическое пособие. Казань : ТГГПУ, 2009. 222 с.

30 Литвинюк А.А. Организационное поведение : учебник. Москва : Издательство Юрайт, 2012. 505 с.

31 Tsymbal S.V. Gamified training sessions as means of enhancing students' motivation in learning English. Psychological Journal. 2018. № 7. P. 151-161. 
Загальна кількість респондентів, котрі взяли участь y формувальному етапі моніторингу, становить 360 осіб.

Для моніторингу рівня сформованості мотиваційного компоненту викладачам була запропонована методика діагностики особистості на мотивацію до успіху Т. Елерса. Анкета містила 41 питання, на кожне 3 яких потрібно було дати відповідь «так» або «ні». Далі потрібно було за ключем підрахувати свої бали. Отримані 1-10 балів свідчать про низьку мотивацію до успіху; 11-16 балів - про середній рівень мотивації, 17-20 балів - про достатній; 21 і більше балів - про високий.

Таблиця 1

\section{Результати проведення анкетування на визначення рівня} мотивації до успіху (за кількістю респондентів)

\begin{tabular}{|c|c|c|c|c|c|c|}
\hline & $\begin{array}{c}\text { 3ВО } \\
\text { № 1 }\end{array}$ & $\begin{array}{c}\text { 3ВО } \\
\text { № 2 }\end{array}$ & $\begin{array}{c}\text { 3ВО } \\
\text { № 3 }\end{array}$ & $\begin{array}{c}\text { 3ВО } \\
\text { № 5 }\end{array}$ & $\begin{array}{c}\text { 3ВO } \\
\text { № 5 }\end{array}$ & $\begin{array}{c}\text { Загальна } \\
\text { кількість } \\
\text { респондентів }\end{array}$ \\
\hline низький & 4 & 3 & 7 & 13 & 8 & $\mathbf{3 6}$ \\
\hline середній & 25 & 28 & 32 & 42 & 33 & $\mathbf{1 6 0}$ \\
\hline достатній & 27 & 20 & 13 & 21 & 13 & $\mathbf{9 6}$ \\
\hline високий & 8 & 14 & 7 & 21 & 20 & $\mathbf{6 8}$ \\
\hline
\end{tabular}

Результати моніторингу (табл. 2) показали, що 10\% викладачів мають низький рівень мотивації до успіху, 44\% - середній, $27 \%$ достатній і $18 \%$ - високий.

Для моніторингу рівня сформованості особистісно-рефлексивного компоненту викладачам була запропонована анкета «Виявлення здібностей до саморозвитку та саморефлексії». Респондентам потрібно було визначити, наскільки кожне із 15 тверджень відповідає чи не відповідає дійсності за такою схемою: твердження повністю відповідає дійсності - 5 балів; швидше відповідає, ніж ні, - 4 бали; і так, і ні 3 бали; швидше не відповідає - 2 бали; не відповідає - 1 бал.

За загальною кількість балів визначався рівень здатності до саморозвитку та саморефлексії, а саме: 1-18 балів - низький рівень, 1937 балів - середній, 38-59 балів - достатній і 60-75 балів - високий.

Результати моніторингу (табл. 2) показали, що 13\% викладачів мають низький рівень сформованості особистісно-рефлексивного компоненту, $34 \%$ - середній, проте 53\% викладачів мають достатній і високий рівні.

Для моніторингу рівня сформованості креативного компоненту викладачам був запропонований тест для оцінки рівня творчого потенціалу особистості. Респондентам було поставлено 18 запитань. У тесті була використана 10-бальна шкала самооцінки особистісних якостей або частоти їхнього прояву, які характеризують рівень розвитку творчого потенціалу особистості. 
За загальною кількість балів визначався рівень творчого потенціалу особистості, а саме: 1-36 балів - низький, 37-73 балів - середній, 74-108 балів - достатній і 109-142 балів - високий рівень.

Таблиця 2

Результати проведення анкетування на виявлення здібностей викладачів до саморозвитку та саморефлексії (за кількістю респондентів)

\begin{tabular}{|c|c|c|c|c|c|c|}
\hline & $\begin{array}{c}\text { 3ВО } \\
\text { № 1 }\end{array}$ & $\begin{array}{c}\text { 3ВО } \\
\text { № 2 }\end{array}$ & $\begin{array}{c}\text { 3ВО } \\
\text { № 3 }\end{array}$ & $\begin{array}{c}\text { 3ВО } \\
\text { № 5 }\end{array}$ & $\begin{array}{c}\text { 3ВО } \\
\text { № 5 }\end{array}$ & $\begin{array}{c}\text { Загальна } \\
\text { кількість } \\
\text { респондентів }\end{array}$ \\
\hline Низький & 5 & 14 & 4 & 20 & 4 & $\mathbf{4 7}$ \\
\hline Середній & 18 & 22 & 17 & 43 & 23 & $\mathbf{1 2 3}$ \\
\hline Достатній & 17 & 14 & 20 & 26 & 23 & $\mathbf{1 0 0}$ \\
\hline Високий & 24 & 10 & 15 & 14 & 27 & $\mathbf{9 0}$ \\
\hline
\end{tabular}

Таблиця 3

Результати проведення тестування на виявлення рівня творчого потенціалу особистості (за кількістю респондентів)

\begin{tabular}{|c|c|c|c|c|c|c|}
\hline & $\begin{array}{c}\text { 3ВО } \\
\text { № 1 }\end{array}$ & $\begin{array}{c}\text { 3ВО } \\
\text { № 2 }\end{array}$ & $\begin{array}{c}\text { 3ВО } \\
\text { № 3 }\end{array}$ & $\begin{array}{c}\text { 3ВО } \\
\text { № 5 }\end{array}$ & $\begin{array}{c}\text { 3ВО } \\
\text { № 5 }\end{array}$ & $\begin{array}{c}\text { Загальна } \\
\text { кількість } \\
\text { респондентів }\end{array}$ \\
\hline Низький & 5 & 14 & 4 & 19 & 4 & $\mathbf{5 6}$ \\
\hline Середній & 18 & 22 & 18 & 43 & 23 & $\mathbf{1 2 5}$ \\
\hline Достатній & 17 & 14 & 22 & 26 & 23 & $\mathbf{8 5}$ \\
\hline Високий & 24 & 12 & 15 & 14 & 27 & $\mathbf{9 4}$ \\
\hline
\end{tabular}

Результати моніторингу (табл. 3) виявили, що 12\% викладачів мають низький рівень творчого потенціалу, $35 \%$ - середній, проте 55\% викладачів мають достатній і високий рівні.

3 метою виявлення основних причин, які гальмують і перешкоджають ефективній інноваційній роботі, нами було проведено опитування, під час якого викладачі повинні були зазначити найбільшу для них причину гальмування інноваційної діяльності. Респондентами були названі такі причини:

- недостатній рівень володіння теоретичними знаннями та практичними уміннями щодо впровадження інноваційних технологій і методів роботи (55 респондентів);

- недостатня матеріально-технічна база в закладі освіти, яка не дозволяе повноцінно здійснювати інноваційну діяльність (127 респондентів);

- нестача часу на саморозвиток через надмірне навантаження (85 респондентів); 
- особисті страхи та психологічна неготовність до здійснення інноваційної діяльності (44 респондентів) та інші причини (50 респондентів).

Серед інших причин, які називали викладачі, були: незацікавленість у професії, низький рівень заробітку, небажання вдосконалюватися, негативне та стереотипне ставлення до інновацій в освіті.

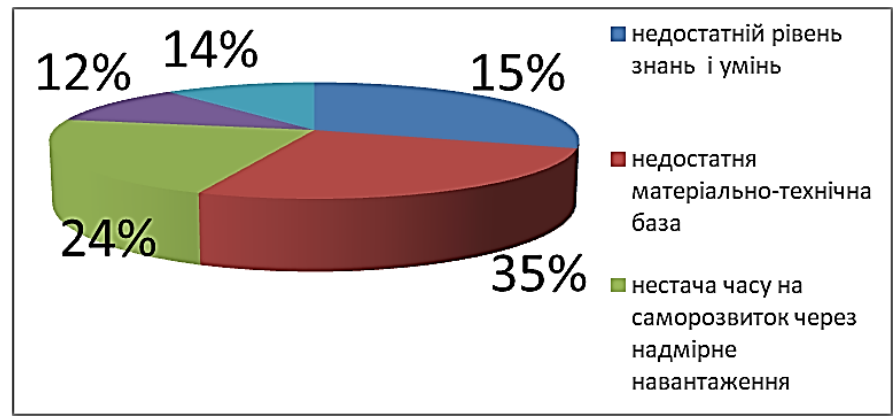

Рис. 1. Причини, що перешкоджають впровадженню інновацій у педагогічній діяльності (у \%)

Таким чином, головною причиною (рис. 1), що заважає $35 \%$ викладачів ефективно впроваджувати інновації в роботі, $\epsilon$ матеріально-технічна база в закладі вищої освіти. Іншими ваговими причинами є недостатня кількість часу на саморозвиток і недостатній рівень знань i уявлень про особливості побудови інноваційного освітнього процесу. Ці причини становлять 39\% від загальної кількості. Лише $12 \%$ викладачів мають особисті страхи щодо впровадження інноваційної освіти.

Оскільки однією зі значущих причин гальмування навчального процесу більшість викладачів зазначили брак знань і вмінь з інноваційної освіти, їм був запропонований опитувальник, у якому слід було обрати основне для них джерело знань щодо інновацій в освіті незалежно від форми проведення (офлайн чи онлайн) із чотирьох запропонованих: Інтернету (різноманітних освітніх сайтів, освітніх платформ); курсів підвищення кваліфікації; друкованих засобів масової інформації (журналів, посібників, методичних рекомендацій); участі у методичних об'єднаннях, семінарах, конференціях, симпозіумах, круглих столах тощо.

Опитуваним пропонувалося назвати декілька джерел, але обов'язково вказати, яке для них $\epsilon$ найбільш ефективним і сприятливим. Серед 360 опитуваних 170 респондентів основним джерелом додаткових знань зазначили Інтернет, 60 - курси підвищення 
кваліфікації, 56 - друковані засоби масової інформації (журнали, посібники, методичні рекомендації), 74 - участь у методичних об'єднаннях, семінарах і конференціях (рис. 2).

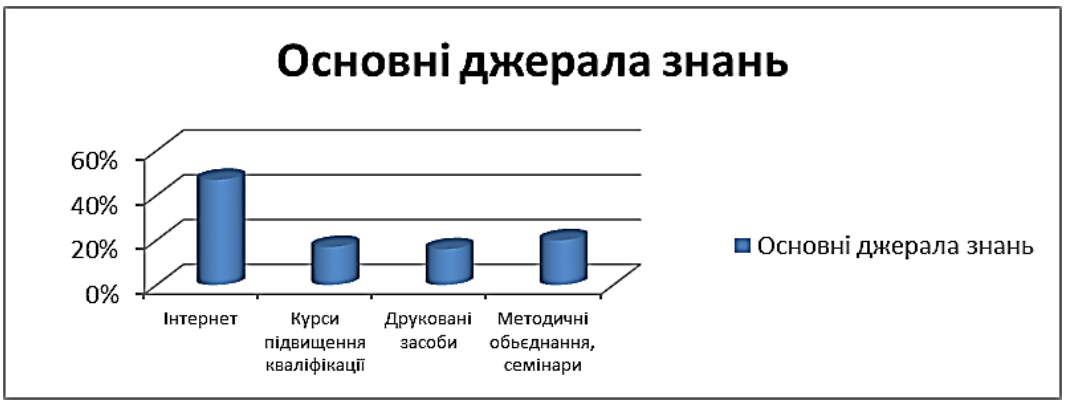

Рис. 2. Джерела, з яких викладачі отримують додаткову інформацію про освітні інновації (у \%)

Таблиця 4

Результати проведення моніторингу щодо професійної готовності викладачів до інноваційної діяльності за компонентами та рівнями (у відсотках)

\begin{tabular}{|c|c|c|c|}
\hline & $\begin{array}{c}\text { Особистісно- } \\
\text { рефлективний }\end{array}$ & Мотиваційний & Креативний \\
\hline Низький & 13 & 10 & 15 \\
\hline Середній & 34 & 44 & 35 \\
\hline Достатній & 28 & 27 & 24 \\
\hline Високий & 25 & 19 & 26 \\
\hline
\end{tabular}

Результати моніторингу засвідчують, що більше 50\% викладачів за усіма компонентами мають високий і достатній рівні професійної готовності до інноваційної діяльності. Це свідчить про значний потенціал викладачів, готових впроваджувати інновації у своїй педагогічній діяльності.

Проте 38\% викладачів мають середній і більше 12\% - низький рівень професійної готовності до інноваційної діяльності за усіма показниками. Це наштовхує нас на висновок про необхідність створення в закладах вищої освіти умов, які би сприяли розвитку вмінь викладачів саморозвиватися та самовдосконалюватися, розвитку науково-методичних, пошукових, дослідницьких умінь і навичок, прагненню підвищення рівня власної інноваційної компетентності. 


\section{ВИСНОВКИ}

Проведений моніторинг виявив певні недоліки в системі професійної підготовки викладачів до здійснення інноваційної педагогічної діяльності, проте дані, отримані під час моніторингу, засвідчують загальну тенденцію до зростання інтересу викладачів до проблеми впровадження інновацій у практику закладів вищої освіти, адже більшість педагогів розуміють таке впровадження як об'єктивну необхідність сьогодення. Водночас було зафіксовано і негативні результати. У процесі опитування виявлено, що певна кількість педагогічних кадрів недостатньо обізнана 3 понятійним апаратом досліджуваної проблеми та методикою іiі впровадження в освітню діяльність.

Необхідність впровадження інноваційних технологій, методів, підходів в освітній процес закладу вищої освіти пояснюється тим, що сучасний етап розвитку української освіти вимагає таких викладачів, які не лише мають відповідний рівень освіти та відповідну кваліфікацію, але й володіють здатністю й уміннями розв'язувати педагогічні проблеми за допомогою інноваційних підходів. Безперечно, успіх інноваційних реформ залежить від педагогічного працівника, його творчого потенціалу, готовності до самовдосконалення та саморозвитку, його професійної компетентності.

Підготовка конкурентоспроможних викладачів із високим рівнем професійної готовності до здійснення інноваційної діяльності потребує трансформації традиційної системи в інноваційну, що передбачає цілеспрямовані зміни, які покращать результати діяльності закладу вищої освіти щодо надання якісних освітніх послуг за допомогою застосування нових технологій управління якістю підвищення кваліфікації та науково-методичного супроводу викладачів до інноваційної діяльності.

\section{АНОТАЦІЯ}

Однією 3 важливих професійних якостей сучасного викладача закладу вищої освіти є готовність до інноваційної діяльності. На основі аналізу літературних джерел авторками з'ясовано сутність ключових понять дослідження: «освітній моніторинг», «професійна готовність», «інноваційна діяльність». У статті проведено моніторинг готовності викладачів до інноваційної діяльності за компонентами та рівнями. Основними компонентами готовності викладачів до здійснення інноваційної діяльності визначено: особистісно-рефлексивний, мотиваційний і креативний. Результати моніторингу засвідчують, що більше $50 \%$ викладачів за усіма компонентами мають високий і достатній рівні професійної готовності до інноваційної діяльності, проте більше ніж у $12 \%$ респондентів не виявлено належного рівня готовності до інноваційної діяльності, а у $38 \%$ цей рівень лише 
середній. Аналіз проведеного авторками моніторингу засвідчує необхідність удосконалення освітньої системи підготовки викладачів щодо впровадження педагогічних інновацій.

\section{ЛІТЕРАТУРА}

1. Блинова В.Л., Блинова Ю.Л. Психологические основы самопознания и саморазвития : учебно-методическое пособие. Казань : ТГГПУ, 2009. 222 с.

2. Буга Н.Ю. Становлення наукової та інноваційної діяльності у вищих навчальних закладах. Економіст. 2006. № 9. С. 60-64.

3. Гончарова О.А. Педагогічні умови підготовки майбутнього вчителя іноземної мови до інноваційної діяльності : автореф. дис. ... канд. пед. наук : 13.00.04. Київ, 2008. 20 с.

4. Дахин А.Н. Педагогический мониторинг: концепция и применение. URL: http://www.iuro.websib.ru/dak.htm (дата звернення: 09.12.2020).

5. Дичківська I.M. Інноваційні педагогічні технології : підручник. Київ : Академвидав. 2012. 352 с.

6. Дичківська I.M. Інноваційні педагогічні технології : навчальний посібник. Київ : Академвидав, 2004. 352 с.

7. Дурай-Новаковская М. Основы и закономерности процесса формирования профессиональной готовности к педагогической деятельности : автореф. дисс. ... докт. пед. наук. Москва, 1983. 41 с.

8. Дьяченко М.И., Кандыбович Л.А. Психологические проблемы готовности к деятельности. Минск : Издво Бел. ун-та, 1976. 175 с.

9. Сльникова Г.В., Рябова 3.В. Моніторинг як ефективний засіб оцінювання якості загальної середньої освіти в навчальному закладі. Культура народов Причерноморья. 2007. № 115. Т. 1. С. 35-43.

10. Зеер Э.Ф., Конюхова Е.Т. Психологические факторы влияния установки педагогов на инновационную деятельность. Образование и наука. 2010. № 4 (72). С. 41-49.

11. Ипполитова Н.В., Колесников М.А., Соколова Е.А. Система профессиональной подготовки студентов педагогического вуза: личностный аспект : монография. Шадринск : Исеть, 2006. 236 с.

12. Кларин М.В. Педагогическая технология в учебном процессе. Москва, 1989. 225 с.

13. Попова О.В. Становлення і розвиток інноваційних педагогічних ідей в Україні в ХХ столітті. Харків : ОВС, 2001. 256 с.

14. Литвинюк А.А. Организационное поведение : учебник. Москва : Издательство Юрайт, 2012. 505 с.

15. Мазур Н. Поняття «Готовності» та визначення структурних компонентів готовності майбутніх вчителів інформатики. Наукові записки Кіровоградського державного педагогічного університету 
імені Володимира Винниченка. Серія : Педагогічні науки. 2013. № 121 (2). C. 283-287.

16. Майоров А.Н. Мониторинг в образовании. Кн. 1. Санкт-Петербург : Образование - Культура, 1998. 344 с.

17. Масленникова В.Ш. Формирование профессиональной готовности студентов среднего профессионального учебного заведения к деятельности социального педагога : автореф. дис. ...докт. пед. наук. Казань, 1996. 38 с

18. Моніторинг якості освіти: світові досягнення та українські перспективи : посібник / за заг. ред. Локшиної О.I. Київ : К.I.C., 2004. $128 \mathrm{c}$.

19. Новий тлумачний словник української мови : у 3 т. / уклад. В. Яременко, О. Сліпушко. Київ : Аконіт, 2001. Т. 3.864 с.

20. Піддубцева О.І. Інноваційні методи формування професійної мобільності майбутніх фахівців-аграріїв. Науковий вісник Національного університету біоресурсів $i$ природокористування України. Серія : Педагогіка, психологія, філософія. 2017. Вип. 277. C. 199-204. URL: http://nbuv.gov.ua/UJRN/nvnau_ped_2017_277_37 (дата звернення: 09.12.2020).

21. Плахотнюк Н.П. Критерії та показники рівня готовності майбутніх учителів до інноваційної діяльності. Збірник наукових пращь Слов'янського державного педагогічного університету. Ч. II. (5). C. $181-191$.

22. Попова О.В. Становлення і розвиток інноваційних педагогічних ідей в Україні в ХХ столітті. Харків : ОВС, 2001. 256 с.

23. Савченко О.Я. Дидактика початкової школи. Київ : Освіта, 1997. $400 \mathrm{c}$.

24. Семак Л.А. Педагогічні передумови формування мовленнєвої компетентності здобувачів вищої освіти. Гуманітарний вісник. 2020. Вип. 32. С. 51-53. URL: http://enpuir.npu.edu.ua/bitstream/123456789/ 29510/1/Hum-Korpus32.pdf\#page=51 (дата звернення: 09.12.2020).

25. Сластенин В.А. Профессиональная готовность учителя к воспитательной работе. Советская педагогика. 1981. № 4. С. 76-84.

26. Сластенин В.А., Подымова Л.С. Педагогика: Инновационная деятельность. Москва : Магистр, 1997. 224 с.

27. Словник іншомовних слів / Л.О. Пустовіт, О.І. Скопненко, Г.М. Сюта, Т.В. Цимбалюк. Київ : Вид-во «Довіра» УНВЦ «Рідна мова», 2000. $1015 \mathrm{c}$.

28. Тарасюк Л.В Моніторинг рівня професійної майстерності вчителя сучасної школи. Теорія та методика управління освітою. T. 1 (22). 2019. URL: http://umo.edu.ua/images/content/nashi_vydanya/ metod_upr_osvit/v_22/\%D0\%A2\%D0\%B0\%D1\%80\%D0\%B0\%D1\%81\%D 1\%8E\%D0\%BA.pdf (дата звернення: 07.12.2020). 
29. Харківська А. Сутність педагогічного моніторингу якості виховного процесу у вищих педагогічних навчальних закладах. Обрiї. 2013. № 2. C. 92-95.

30. Хриков Є.M. Теоретико-методологічні засади моніторингу професійної підготовки. URL: http://www.prof.osvita.org.ua/uk/career/ articles/2.html (дата звернення: 09.12.2020).

31. Щоголєва Л.О. Моніторинг якості освіти: теоретикометодологічний аспект. Педагогічний пошук. 2014. № 2 (82). С. 36-40.

32. Tsymbal S.V. Gamified training sessions as means of enhancing students' motivation in learning English. Psychological Journal. 2018. № 7. P. 151-161.

\section{Information about the authors: Rezunova O. S.,} Candidate of Pedagogical Sciences, Associate Professor, Associate Professor at the Philology Department Dnipro State Agrarian and Economic University 25, S. Yefremov str., Dnipro, 49600, Ukraine

Perederii O. L.,

Candidate of Pedagogical Sciences, Associate Professor at the Preschool and Primary Education Department Communal Institution of Higher Education "Dnipro Academy of Continuing Education" of Dnipropetrovsk Regional Council 70, V. Antonovych str., Dnipro, 49000, Ukraine 